\title{
Clubes barriales de la ciudad de Santa Fe: diagnóstico y prognosis
}

Sports Clubs in the Neighbourhoods of Santa Fe City:

Diagnosis and Prognosis

Clubes de bairro da cidade de Santa Fe:

diagnóstico e prognóstico

María Rut Azerrad

Facultad de Ciencias Económicas,

Universidad Nacional del Litoral,

Santa Fe, Argentina

E-mail:mazerrad@fce.unl.edu.ar

Germán Rossler

Facultad de Humanidades y Ciencias,

Universidad Nacional del Litoral,

Santa Fe, Argentina

E-mail: rosslergerman@gmail.com
Emir Espinoza

Facultad de Ciencias Económicas,

Universidad Nacional del Litoral,

Santa Fe, Argentina

E-mail: eespinoza@rectorado.unl.edu.ar

María Alicia Barletta

Facultad de Ciencias Económicas,

Universidad Nacional del Litoral,

Santa Fe, Argentina

E-mail:mabarletta@fce.unl.edu.ar
Fecha de recepción: 22/04/2020

Fecha de aceptación: 26/06/2020

Palabras clave

- clubes barriales

- economía social y solidaria

- diagnóstico

- propuesta metodológica

\section{Resumen}

El presente artículo tiene como objetivo presentar un diagnóstico de situación respecto a una población objetivo de cien (100) clubes barriales de la ciudad de Santa Fe, el cual surge de un trabajo de campo realizado en conjunto por la cátedra electiva y optativa de Economía Social y Solidaria (ESyS) y un Proyecto de Extensión de Interés Social de la Facultad de Ciencias Económicas (FCE) de la Universidad Nacional del Litoral (UNL), a partir de una demanda de la Secretaría de Desarrollo Social del Gobierno Local, la Subsecretaría de Deportes y, más específicamente, a través de la Dirección de Deportes y del Programa Clubes. Posteriormente a partir del diagnóstico realizado se presenta la propuesta metodológica de trabajo que posibilita un acompañamiento en red desarrollando un proceso de alfabetización continuo e integral.

\footnotetext{
Abstract

IThe purpose of this article is to present a diagnosis of the situation of one hundred sports clubs located in different neighbourhoods of Santa Fe city, which arises from a fieldwork carried out jointly by the elective and
} 
Keywords

- sports clubs in neighbourhoods

- Social and Solidarity Economy

- diagnosis

- methodological proposal

Palavras-chave

- Clubes de bairro

- Economia Social e Solidária

- Diagnóstico

- Proposta metodológica optional course Social and Solidarity Economy and a Social Interest Extension Project from the School of Economic Sciences (FCE) of Universidad Nacional del Litoral (UNL). This research aimed to meet a demand from the Secretariat of Social Development of the local Government, the Undersecretariat of Sports and, more specifically, the Directorate of Sports and the Clubs Programme. Subsequently, based on the diagnosis, we present the methodological proposal to work with these organisations by accompanying them and by developing strategies for a continuous and comprehensive literacy process.

\section{Resumo}

0 presente artigo procura apresentar um diagnóstico de situação a respeito de uma população alvo de cem (100) clubes de bairro na cidade de Santa $\mathrm{Fe}, 0$ que decorre de um trabalho de campo realizado conjuntamente pela cadeira eletiva e optativa de Economia Social e Solidária (ESeS) e um Projeto de Extensão de Interesse Social da Faculdade de Ciências Econômicas (FCE) da Universidade Nacional do Litoral (UNL), a partir de uma demanda da Secretaria de Desenvolvimento Social do Governo Local, da Subsecretaria de Esportes e, mais especificamente, através da Diretoria de Esportes e do Programa Clubes. Posteriormente, com base no diagnóstico realizado, apresenta-se a proposta metodológica de trabalho que permite um monitoramento em rede desenvolvendo um processo de alfabetização continuo e abrangente. 